\title{
Skræk i forebyggelseskampagner - stærkt virkemiddel eller skråplan?
}

\author{
Af Birgitte Ravn Olesen, Tine Mark Jensen og Nina Blom Andersen
}

\begin{abstract}
I artiklen sattes fokus på hoilke faktorer, det er relevant at inddrage i en diskussion af, hvorvidt skrak er et anbefalelsesverdigt virkemiddel $i$ sundhedsfremmende kampagner. Udgangspunktet tages $i$ en begrebsmessig afklaring affenomenet »skrak som virkemiddel", hoor eksempler fra danske kampagner inddrages. I forlangelse herafudpeges en rakke faktorer, som forfatterne mener, bor have fokus i vurderingen af, hoorvidt skrak er et relevant virkemiddel. Formålet med artiklen er at invitere til refleksion omkring, hvilke faktorer og effekter, man skal vare opmerksom på ved sit valg af virkemidler, når man har valgt kampagnen som formidlingsform.
\end{abstract}

Der er siden begyndelsen af 1990'erne gjort mange erfaringer med forskellige typer af kampagner, hvis mål har været at få danskerne til at leve sundere. Brugen af virkemidler og medier har været varierende, det samme har effekten. Et generelt træk ved kampagnerne er, at henvendelsesformen overvejende grad er karakteriseret ved top-downorienteret lineær kommunikation. Et andet generelt træk er, at effekten nogle gange kan ses på opmærksomhed og viden (rygning, alkohol sundhedsstyrelsen), mens handlingselementet vurderes som begrænset. Med en stor mængde erfaringer og en begrænset mængde ressourcer bliver det derfor relevant at spørge: Hvad kan gøres anderledes?

En mulighed er at anvende andre og skrappere virkemidler. Skræk har indtil nu ikke været et udbredt virkemiddel inden for dansk forebyggelse. I starten af 1990'erne var der f.eks. stor forskel på Danmarks og Australiens brug af skræk i AIDSoplysning. I Danmark satsede man på humor som virkemiddel, hvor man i Australien i højere grad satsede på at »true« folk til at handle anderledes.

I dag har vi set de første skrækkampagner i Danmark. Med udgangspunkt i et litteraturstudie ${ }^{1}$ af international forskning inden for feltet »effekter af skræk som virkemiddel«, som vi har foretaget for Sundhedsstyrelsens dokumentationsenhed, ønsker vi at pege på en række faktorer, som er relevante, hvis man overvejer i stigende grad at anvende skræk som virkemiddel i Danmark.
Før vi diskuterer disse faktorer vil vi foretage en begrebsmæssig afklaring af fænomenet »skræk som virkemiddel«. Det er nemlig ikke så ligetil at afgøre, hvad der egentlig - generelt og alment - kan ventes at blive opfattet som skræk.

\section{En begrebsmassig afklaring af fænomenet "skræk som virkemiddel"}

Skræk er et relativt begreb, da mennesker opfatter tekst, billeder og budskaber individuelt $\mathrm{i}$ forhold til berøring med emnet, erfaringer mv. Når fokus er på sundhedsfremme handler skræk bl.a. om at fokusere på negative konsekvenser af bestemte handlinger, f.eks. sygdom og død. Det vil sige, at individets oplevelse af en risiko for at lide tab er et centralt element i definitionen af skræk. R.W. Rogers skriver:

"A fear appeal is defined as a persuasive communication that presents threatening information to arouse fear in order to promote safer behavior. Threatening information comprises of information that presents a problem that has serious negative consequenses to which the target person believed to be susceptible". (Rogers, R.W. (1983))

Vi har ikke fundet en definition, som er mere præcis end denne. I nogle studier af skræk som virkemiddel skelnes mellem »low fear« og »high fear«, uden at der gøres nærmere rede for, hvordan disse begreber er fremkommet og uden at de sættes i 
relation til specifikke målgrupper. For eksempel må man antage, at et budskab om, at rygning nedsætter levealderen, vil have forskellig effekt hos en 60-årig og en 20-årig ryger og individuelle forhold, f.eks. viden om, at man er arveligt disponeret for at få blodpropper, kan gøre, at et nøgternt udsagn om denne type risici opleves som et skrækbudskab.

De færreste studier viser de testede tekster og billedmateriale. Et eksempel på et fremvist billedmateriale er en tegning af en barm med bh med underteksten »Save the contents«. (Collins m.fl. 1997) Dette er ifølge studiet og Rogers definition et skrækbudskab, da der udpeges mulige tab, hvis man ikke får forebyggende mammografi-undersøgelser.

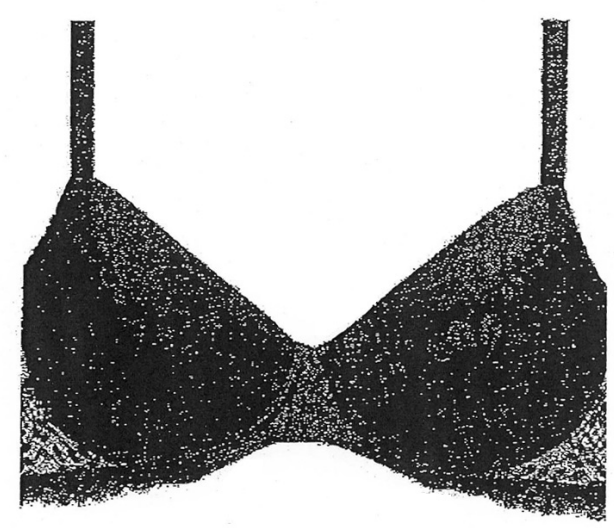

\section{SAVE THE CONTENTS.}

Get a mammogram. And detect cancer up to two years before you can. Early detection saves lives.

Et lignende eksempel fra en dansk kampagne, der også benytter skræk inden for denne definition, er en alkoholkampagne fra Sundhedsstyrelsen (1999). Den viser en kvinde siddende træt på sengekanten og manden ligger bagved. Billedets undertekst lyder: »For meget alkohol, for lidt sex«.

Nogle forbinder ikke disse eksempler med skræk. Skræk associerer blod og død - fx kræftsvulster på rygerlunger, trafikulykke med sårede etc. Men fastholder vi, at fokus på negative konsekvenser af en given handling, er et centralt element i skræk, så hører ovenstående eksempler med. Det implicerer, at det kan være relevant at se skræk som virkemiddel i et kontinuum, hvor faktuelle udsagn om risici ved forhøjet blodtryk og stærke følelsesmæssigt appellerende videospots af en kvinde, som falder om som følge af en blodprop, ligger i hver sin ende. Vores pointe i denne sammenhæng er, at der ikke kan opstilles entydige definitioner for, hvad der opleves som skræmmende og det derfor er betydningsfuldt at undersøge individuelle receptioner af billeder og budskaber hos repræsentanter for den valgte målgruppe.

Eksempler på skrækbudskaber:

- Visualisering (still og levende billeder) af skader pga. en bestemt handling- rygerlunger, hudkræft pga. for meget sol mm. Senest har Rådet for Større Færdselssikkerhed gennemført en kampagne, hvor de viste konsekvensen ved manglende brug af sikkerhedssele - død. Det ene spot uden blod - det andet med.

- Skriftbaseret materiale som de nye labels på cigaretpakker, hvor det f.eks. lyder: "Rygning er yderst skadelig for dig og dine omgivelser", "Rygning nedsætter levealderen", "Rygning kan nedsætte blodgennemstrømningen og medfører impotens".

- Dialog og personlig fortælling, som særligt har været brugt i trafikkampagner, hvor unge, som selv er kørt galt pga. for høj fart og evt. spiritus, fortæller om deres liv efter bilulykker. En sådan kommunikation er ikke aggressiv i sin form, men kan med stor sandsynlighed skabe identifikation og dermed virke skræmmende på nogle. Den personlige fortælling bruges ligeledes i oplysningsvideoer bl.a. ved narkotikaforebyggelse og AIDS-oplysning.

Skræk som virkemiddel er altså ikke forbeholdt et bestemt medie. Det kan bruges i den direkte dialog, i pjecer, i tv-spot, videoer, på labels, i undervisningsmateriale $\mathrm{mm}$.

Hvorvidt skræk kan virke som drivkraft til at få mennesker til at ændre deres handlinger har optaget adfærdspsykologer i årtier. I 1950'erne lancerer Hovland, Janis \& Kelly »drivemodellen«. Tankegangen er, at et sundhedsbudskab, der skaber emotionel frygt vil føre til en emotionel spænding, som opleves som ubehagelig og som modtageren derfor vil ønske at reducere. Derfor vil modtageren acceptere og følge anbefalingen. 
Modellerne opererer med en linearitet - ved den rette dosering skræk føler folk sig sårbare og vil imødegå angsten/truslen ved at følge de handlingsanvisende budskaber. (se Rise, 2001)

Siden er der udviklet andre $»$ Drivemodeller«. De to modeller som oftest bliver anvendt i nyere forskning er Protection Motivation Theory (PMT modellen) og The Extended Parallel Process Model (EPPM). Disse modeller nuancerer i nogen grad tankegangen om, at skræk automatisk virker som en drivkraft i forhold til at ændre handlinger. I følge PMT-modellen, som er udviklet af R.W.Rogers, er et skrækbudskab effektivt, hvis følgende fire betingelser er opfyldt:

- Personen oplever at han/hun er modtagelig over for truslen.

- Oplever truslen som alvorlig.

- Tror den anbefalede handling kan fjerne truslen.

- Oplever at han/hun er i stand til at rette sig efter budskabets anbefaling.

EPPM-modellen indeholder i hovedtræk de samme komponenter som Protection Motivation Theory (PMT-modellen). Men i EPPM nuanceres individets evne til at handle på baggrund af budskabet og handlingsanvisningerne, hvilket betyder, at modtageren kan reagere ved enten at ændre på sine handlinger (danger control) eller benægte eksistensen af et problem (fearcontrol).

Sagen er ifølge EPPM, at hvis modtageren oplever lav risiko, så er der ingen reaktion på skræk og dermed ingen handling. Ved oplevelse af høj risiko kombineret med god mulighed for handling vil modtageren søge at ændre sine handlinger (danger control). Men opleves risikoen som høj samtidig med at modtageren ikke oplever at kunne handle og mangler tro på at en handling vil hjælpe, så fører det til afvisning af budskab eller benægtelse (fear control).

Et sådant eksempel findes i en undersøgelse Vilstrup Research har foretaget for Sundhedsstyrelsen. Her blev en række tv-spots om risici ved rygning testet på 4 udvalgte målgrupper. Testen viste blandt andet, at reklamerne generelt var gode til at skabe dårlig samvittighed og tanker om at ophøre med at ryge hos de udvalgte målgrupper, men at en mindre andel reagerede med at tage afstand fra reklamerne. Det kom til udtryk i udsagn som »Det er lige så usundt at trække vejret på gaden med al den forurening, som at ryge« og »Man kan jo også få kræft af tilsætningsstoffer i maden«. Sidstnævnte gruppe reagerer således med fear control. (Vilstrup Research, 2003)

På hver sin måde er modellerne simplificerede forklaringer (eller hypoteser) på, hvad der sker, når folk bliver konfronteret med et skrækbudskab.

EPPM- og PMT modellerne er omdrejningspunkt i mange af de artikler, der indgår i litteraturstudiet (se f.eks. Witte, 2000, Floyd, 2000, Kline and Mattson, 2000) ${ }^{2}$ Et eksempel på brug af modellen finder vi hos Stephenson og Witte, som med grundlag i EPPM-modellen, tester en række skræk-budskaber relateret til solbadning med henblik på at opfordre til at beskytte sig mod solskoldning. Skræk-budskaberne blev fulgt op af en række forslag til, hvordan man kan beskytte sig og de blev præsenteres for en gruppe college-studerende. Konklusionen er, at skræk-budskaber er effektive, når det gælder beskyttelse mod solskoldning. Jo mere skræmmende, jo højere effekt, når budskabet er koblet til en tydelig angivelse af muligheder for at beskytte sig. (Stephenson MT og Witte K, 1998)

Anvendelsen af modellerne sker både, når forskerne overvejende er positive overfor anvendelse af skræk og når de er kritiske i forhold til det. Kritikerne ser modellerne som alt for enkle og lineære og påpeger især, at der ikke tages højde for menneskers individuelle baggrund.

Forskningsresultaterne giver ikke et entydigt svar på, hvorvidt det er hensigtsmæssigt at bruge skræk som virkemiddel i kampagner, som har til formål at få folk til at handle anderledes. En gruppe forskere er positive over for at bruge skræk kombineret med handlingsanvisninger. I deres modeller og teoretiske argumentation ligger en antagelse om, at mennesker ved den rette dosering skræk føler sig sårbare og derfor vil imødegå angsten/truslen ved at følge de handlingsanvisende budskaber. (Stephenson m.fl., 1998, Struges m.fl. 1996, Witte m.fl. 2000, Floyd, 2000) En anden gruppe forskere finder i deres undersøgelser belæg for, at det er hensigtsmæssigt at lægge vægt på fordelene ved at ændre sine handlinger. (Keller, 1996, Johnson og La Tour, 1991) På tværs af holdning til appel- 
former er forskerne enige om, at skrækbaseret information altid må følges op af handlemuligheder, som er realistiske for målgruppen.

Nogle forskningsresultater og evalueringer af skrækkampagner peger på, at en af fordelene ved at bruge skræk er, at modtagerne generelt opfatter budskabet som mere troværdigt og seriøst end kampagner, der ikke bruger skræk. (Rise, 2001, Australia's National Tobacco Campaign, 2000) Endvidere ser skræk ser ud til at virke i forhold til de allerede overbeviste eller dem, der overvejer at ændre deres handlinger.

Endelig kan brug af skrækvirkemidler sætte et spørgsmål på den offentlige dagsorden, så længe det er nyt og med fare for, at det bliver formen snarere end budskabet, der er i fokus. En vedvarende brug af skræk kan føre til, at modtagerne lukker af overfor budskaber, som appellerer til deres frygt. (Windahl og Signitzer, 1998)

Efter denne redegørelse for begrebet skræk som virkemiddel og introduktion til de dominerende modeller for menneskers reaktion på et skrækbudskab, som en væsentlig del af den internationale forskning refererer til, vil vi fremlægge og diskutere en række relevante faktorer ved vurdering af, hvorvidt skræk er et relevant virkemiddel i en specifik kampagnesammenhæng. Vi indleder med at præcisere, at udpegning af målgruppen for en kampagne er meget vigtigt, men også kompliceret og krævende. Her efter præsenteres forskellige forhold i relation til såvel den udpegede målgruppe som til andre aktører i samfundet. Til slut fremlægges et perspektiv på viden om sundhed, som i sig selv problematiserer sundhedskampagnestrategier og som bliver særligt relevant, hvis skræk tænkes brugt som virkemiddel.

\section{Udfordring af målgruppesegmentering}

Ligesom frygt- og skrækappeller er forskellige, så ser vi snarere målgrupper som en analytisk kategori end som en konkret gruppe mennesker, der kan udpeges i praksis. Sagt på en anden måde, så er menneskers relevansoplevelse og handleberedskab i forhold til et givet emne ikke entydigt og konstant. Vi må snarere se det som kontekst- og relationsaf- hængigt, hvilket stiller krav til formidleren om, at arbejde med et refleksivt målgruppebegreb.

Der findes et utal af segmenteringsmodeller. I bogen »Using Communication Theory« introduceres f.eks. til segmentering ved biografiske karakteristika, ved oplevelse, ved holdning, ved handlinger, ved adgangsmuligheder, ved økonomiske, sociale og kulturelle ressourcer, ved niveau i beslutningsproces, ved mediebrug og ved sagsforholdets betydning i offentligheden. (Windahl, Olson og Signitzer, 1998)

En anden tilgang findes hos William McGuire. Han har udviklet en model, som kan bruges til at vise de kræfter, der driver forskellige modtagere til at bearbejde en påvirkning på en bestemt måde. McGuire fremlægger 16 dynamiske teorier om forskellige aspekter ved motivation, hvor han fokuserer på, hvordan nogle motiveres mest følelsesmæssigt, nogle mest rationelt, nogle af noget der kan føre til stabilitet og andre igen af noget, der kan føre til udvikling. Enkle løsninger findes ikke. (McGuire, 1989)

Modellerne er hver især gode at tænke med, men de er også forførende, fordi de kan få os til at tro, at vi med dem $i$ hånden kan afgrænse og udpege den målgruppe, vi vil henvende os til. Menneskers hverdag, erfaringer og handlinger er langt mere komplekse end modeller inviterer os til at tro.

Det betyder ikke, at vi lige så godt kan opgive at afklare, hvilken målgruppe, vi skal henvende os til. Tværtimod vil vi argumentere for, at vi i arbejdet med målgruppen må søge at forholde os til den kompleksitet, som karakteriserer menneskers liv. Det gøres bedst ved at gå empirisk til værks, således, at vi tegner komplekse billeder af vores målgruppe og arbejder med hypoteser om den allerede i kampagnedesignfasen. Her nævnes nogle af de parametre, vi finder særligt relevante i relation til spørgsmålet om, hvorvidt skræk er et relevant virkemiddel.

\section{Individets oplevelse af relevans som parameter}

Oplever individet at den trussel, som formidles, er relevant i forhold til hendes hverdagsliv? Individets reaktion på en skrækappel, vil afhænge af, hvilke 
erfaringer, hun bærer med sig og hvilke kulturelle koder, der er dominerende $\mathrm{i}$ hendes hverdagsliv. Hun bærer med andre ord en relevans-struktur, som gør nogle udsagn og henvendelsesformer mere betydningsfulde og nærværende end andre. (Schutz, 1975) Alfred Schutz bruger begrebet »tema« om de emner, som i kraft af individets subjektive erfaringer og mål opleves som relevante.

Hvis individet, når hun for eksempel møder et budskab om alkoholforbrug ikke kan relatere det til sit liv, så er det ikke et tema. Det er simpelthen betydningsløst. Afsenderens eneste mulighed er da at prøve at give det betydning, at gøre det til et tema. Første skridt kan være at introducere sin egen afsender-forståelse af, at sundhed handler om at have det godt - ikke alene om ikke at være syg. Anerkendes denne forståelse, så kan næste skridt være at få personen til at reflektere over eller lytte til udsagn om, at alkoholindtagelse har betydning for ens sundhed og velvære. Tredje skridt kan være at få knyttet den generelle præmis til personens eget liv. Først her - og der kan være rigtig lang vej - begynder overvejelser omkring at ændre sine handlinger.

En forudsætning for, at denne proces bliver vellykket er, at der hos både afsender og modtager er en vilje til at være en del af en fælles samtale. Der skal være dialog, der skal være vilje til »fællesskab«. (Dahl, 1993)

Autoritative budskaber, som ikke levner plads til andre virkelighedsopfattelser, vil på denne baggrund stå i fare for at blive forkastet. Spørgsmålet bliver derfor om et skrækbudskab kan være en invitation til dialog eller der snarere er risiko for, at aktører, som ikke selv anser budskabet for relevant overser eller reagerer imod det (se nedenfor om boomerangeffekt). (Keller 1996, 1999)

Hændelser i den enkeltes hverdagsliv som skaber personlig relevans er en meget kraftfuld faktor, når det gælder at ændre sine handlinger. Vi har ofte på vores kurser bedt vores studerende om at overveje, hvornår de sidst kan stadfæste, at de har ændret deres handlinger og siden ladet dem interviewe hinanden om, hvad der var årsagen til, at de valgte at ændre den nævnte handling. Et gennemgående valg af ændret handling er rygeophør. Årsagerne til dette kan være »min venindes far døde af lunge- kræft« «, »jeg blev gravid « og »jeg fik en kæreste, som syntes, at det var ulækkert at kysse en ryger«. Det er altså karakteristisk, at rygning bliver et tema og at det opleves som personligt relevant at gøre noget ved. De 3 udsagn om årsager til rygeophør handler på forskellig måde om at blive opmærksom på, at man kan opnå noget efterstræbelsesværdigt ved at lægge smøgerne på hylden.

\section{Handleberedskab som parameter}

Ofte tager målgruppesegmentering udgangspunkt i parametre som køn, alder, uddannelsesniveau, boligforhold og andre demografiske faktorer. Vi vil her argumentere for, at man med fordel kan bruge Pierre Bourdieus analytiske greb »habitus« og »kapital« som parametre. Habitusbegrebet gør det muligt at sammentænke blandt andet livsform, perceptionsmåder, krop og erfaringer hos individet. Bourdieu siger selv, at »habitus er resultatet af en internalisering af eksterne strukturer«. (Bourdieu og Waquant, 1992; 30)

Individets habitus er tæt knyttet til dets kapital. Hos Bourdieu er kapital karakteriseret ved at være noget som tillægges værdi i samfundet. Han udpeger besiddelsen af økonomisk, kulturel og symbolsk kapital som afgørende for den habitus som udvikles over tid og i tæt samspil med de sociale strukturer, der er omkring individet. (Bourdieu, 1990) Det betyder, at individets besiddelse af kapital har betydning for hvilket handlerum, hun har. (Poulsen, 1999)

Økonomisk kapital kan i relation til sundhedsfremme handle om, hvad individet har råd til at købe (fedtfattige varer er ofte dyrere end fedtholdige), kulturel kapital kan handle om, hvad det er man gør, når man er »usund« (nogle deler en flaske vin fredag aften, andre deler en flaske vodka) og symbolsk kapital kan handle om, hvordan man forstår sig selv (»jeg gennemfører, hvad jeg sætter mig for« kontra »jeg klarer nok ikke opgaven«).

Habitus åbner for uendeligt mange handlemuligheder, men der er også begrænsninger, som er betinget af individets akkumulerede erfaringer med at handle i praksis og de sociale strukturer omkring individet. Et eksempel: Har individet erfaring med at kunne træffe beslutninger for sit eget liv og er- 
faring med at kunne fuldføre planlagte projekter (eller fastholde sit selvværd, hvis ikke det lykkes), så er sandsynligheden for, at et (skræk)budskab kombineret med handlingsanvisning kan få effekt langt større, end hvis individet ikke har akkumuleret denne type erfaringer. Omvendt kan individet med stor symbolsk og kulturel kapital- og dermed et stort handlerum - også være den, der ser det som en mulighed at afvise budskabet til trods for risikoen for at lide tab - udsagn som »det er sandt, at det er usundt at ryge, men det giver mig en livskvalitet, jeg ikke vil undvære«, viser, at individet ser det som en mulighed at vælge mellem flere mulige handlinger.

Fokus på livsform, perceptionsmåder, krop og erfaringer hos den eller de grupper, man ønsker at få kontakt til gennem en forebyggelseskampagne sætter den sociale kontekst for målgruppen og de erfaringer med at skabe forandring, individer $\mathrm{i}$ målgruppen har, på dagsordenen.

Vi vil også blive tvunget til at forholde os til de sociale kontekstmarkører, der ligger i kampagnens budskab. Et eksempel på, hvordan det kan gå, når man ikke er opmærksom på den kontekst, kampagnens handleanvisninger udpeger findes hos Eva Thune Jacobsen. Hun refererer et interview med en mand, som drikker en del øl for at sige »jeg kan sgu da ikke sætte vand ind til bajeren«, da talen falder på anbefalingen i en aktuel alkoholkampagne. Hun påpeger hermed, at manden lægger kulturel afstand til en kampagne, som råder til at drikke vand til vin. Kampagnen henvender sig således til mennesker med en vinalkoholkultur, som er fjern fra den bajerkultur, manden kender til. (Jacobsen, 92)

I eksemplet er det indlysende, at kampagnen i sine handlingsanvisninger retter sig mod individer med en anden symbolsk kapital og nogle andre praksiserfaringer end den interviewede mand. Men hvor ofte signalerer ikke møblement på fotos (barnet $\mathrm{i}$ trip-trap-stolen) eller handlingsanvisningen (lad bilen stå, når du henter morgenbrød), at henvendelsen ikke gælder mennesker med en anden smag (symbolsk kapital) eller andre ressourcer (økonomisk kapital) end dem, der anvendes i de dominerende diskurser?

\section{Niveau i beslutningsprocessen som parameter}

Den sidste parameter, vi her vil sætte fokus på, er individets aktuelle motivation i forhold til at forandre sine handlinger.

Prochaska m.fl. har med opstillingen af en femtrinsmodel, hvor første niveau er for emnet overhovedet bliver genstand for refleksion (et »tema« $\mathrm{i}$ Schutz' forstand) og sidste niveau er fastholdelse af nye handlinger, påpeget sammenhænge mellem, hvor individet er i sin beslutningsproces og hvordan hun modtager et budskab. (Prochaska, DiClemente, Norcross, 1992)

Er individet i en situation, hvor hun allerede har overvejet at holde op med at ryge, men blot ikke har taget sig sammen endnu, har hun dårlig samvittighed over at ryge, men uden konkrete planer om at stoppe eller er hun tilfreds med at være ryger?

Keller m.fl.(1996, 1999)vurderer på baggrund af egne undersøgelser og diskussion af foreliggende forskning, at skræk har positiv indflydelse på menneskers beslutningsproces eller opretholdelse af nye handlinger, hvis de finder emnet relevant og allerede er i færd med at overveje at ændre deres handlinger.

Betydningen af individets erfaringer og aktuelle situation i forhold til oplevelsen af skræk og valg af handlinger understøttes af Jonson og La Tour (1991). Deres undersøgelse tyder på, at de mest seksuelt aktive mænd og kvinder, som derfor også hører til i høj-risikogruppen, bliver mest irriterede på kampagnen for brug af kondomer.

Undersøgelser peger således i retning af, at den motiverede kan få et sidste skub ved at møde en skrækappel, mens den usikre formodentlig blot vil blive bekræftet i, at hun ikke burde ryge og dermed samlet set få forværret sin livskvalitet, og den bevidste ryger vil afvise budskabet. (Prochaska, 1994)

Ved evaluering af effekt af en kampagne er det relevant at have øje for mindre synlige effekter; er rygefrekvensen f.eks. nedsat i målgruppen, er der flere, som siger, at de overvejer at holde op med at ryge i nær fremtid eller er blevet mere opmærksomme på deres rygning, så kan det være tegn på, 
at kampagnen har bidraget til, at der er sket forskydning i beslutningsstadierne i målgruppen.

\section{Hvordan håndtere disse parametre?}

Meget kort er vores svar, at arbejdet med at finde den relevante målgruppe og afklare, hvad der giver mening for denne ikke kan ske ved et skrivebord. Der er ikke andre veje end at udfolde forskellige metoder, som har til formål at få indsigt i de mennesker, man ønsker, skal ændre deres handlinger.

Brenda Dervin har med »Sense-making « metoden introduceret en måde at finde og forstå målgrupper på. Tanken bag metoden er, at alle mennesker søger at optimere deres mulighed for at leve et godt liv ud fra de muligheder, de oplever at have. I arbejdet med at optimere egne muligheder, støder man på situationer, hvor man mangler information. Det er på dette - og kun på dette - tidspunkt, individet er interesseret $\mathrm{i}$ at få information. Til gengæld er hun meget lydhør og engageret, hvis hun møder forståelse for sit behov og handlingsanvisninger, som hun kan bruge i sit eget liv. (Dervin, 1989, Dervin and Foreman-Wernet, 2003)

Dervin interviewer derfor mennesker om, hvordan deres aktuelle situation er, hvad de tænker om det tema, man overvejer at lave kampagne om og hvad der har betydning for, at de tænker og handler som de gør i forhold til temaet. Spørgsmålene kommer til at lyde i retning af: Nogle taler meget om motion, har du hørt om det? Hvad har du hørt om motion? Hvad betyder det for dig i din hverdag? Hvornår har du sidst stået i en situation, hvor du overvejede at dyrke motion? Hvorfor overvejede du det på det tidspunkt? Hvad gjorde du så? Hvad kunne få dig til at gøre noget andet i forhold til motion? Hvad er de største hindringer for at fă motion ind i din hverdag? osv.

Dervin forholder sig ikke alene til selve interviewet, hun har også klare bud på, hvem det er relevant at interviewe. En central pointe er, at mennesker ses som decentrerede, de tænker og handler ikke ens over tid og i forskellige kontekster. Derfor må vi interviewe mennesker på mange stadier og i mange kontekster i forhold til vores tema. Her et eksempel på, hvem det vil være relevant at tale med før design af en stop-rygning-kampagne:
- ikke-rygere om, hvorfor de ikke ryger

- rygere, som har forsøgt at holde op 1 gang, hvor det lykkedes

- rygere, som har forsøgt at holde op 1 gang, hvor det ikke lykkedes

- rygere, som har forsøgt at holde op 50 gange, hvor det er lykkedes

- rygere, som har forsøgt at holde op 50 gange, hvor det ikke er lykkedes

- rygere, som aldrig har forsøgt at holde op

Spørgsmålene går så på, hvad der giver mening for disse mennesker, hvad har motiveret dem, hvad har afskrækket dem, hvad har fået dem til at tage afstand. I interviewet kan oplevelse af relevans, handlingsberedskab og stadier i beslutningsprocessen indgå som relevante parametre, som får substans gennem konkrete fortællinger.

\section{Ikke-intenderede effekter}

Uanset valg af kampagnestrategi og målgrupper, så risikerer man som afsender, at budskab og valgte virkemidler har ikke-intenderede effekter. Jo stærkere virkemiddel, man som afsender vælger, jo større krav er der til at overveje ikke-intenderede effekter. Vi vælger her først at sætte fokus på forskning, som udpeger risici for en såkaldt boomerangeffekt ved brug af skræk som virkemiddel, herefter diskuteres etiske implikationer af at bruge skræk og endelig sættes brugen af skræk ind i en større samfundsmæssig kontekst.

\section{Boomerang}

En vigtig parameter for et budskabs effekt er, at det bliver genstand for opmærksomhed i målgruppens indbyrdes kommunikation. Refererer eleven filmen om xx hjemme ved aftenbordet, fortæller kollegaen om pjecen om yy ved frokosten, således, at emnet bliver genstand for diskussion og refleksion i den enkeltes netværk, hvor holdningsdannelse foregår?

Hvis ja, så er der virkelig noget, som er lykkedes. Men enhver spredning betyder også, at budskabet tilpasses og omformes i forhold til målgruppens perspektiv og interesser. I denne tilpasningsproces kan en såkaldt boomerang-effekt opstå. Enhver kampagne kan diskuteres i forhold til sin hensigt, men den kan også blive genstand for humoristiske omformuleringer eller fælles front imod det formidlede budskab. (Rogers, 1995) 
Som formidler risikerer man, at formidling med skræk som virkemiddel kan give en boomerangeffekt i form af større interesse for en bestemt handlinger og at skræk kan bidrage til at fremme en antiautoritær holdning i målgruppens sociale netværk. For a vise over for sig selv, at man er et selvbestemmende individ, fortsætter man handlingen og laver måske en direkte offensiv som www.sjovtobak.dk er et eksempel på.

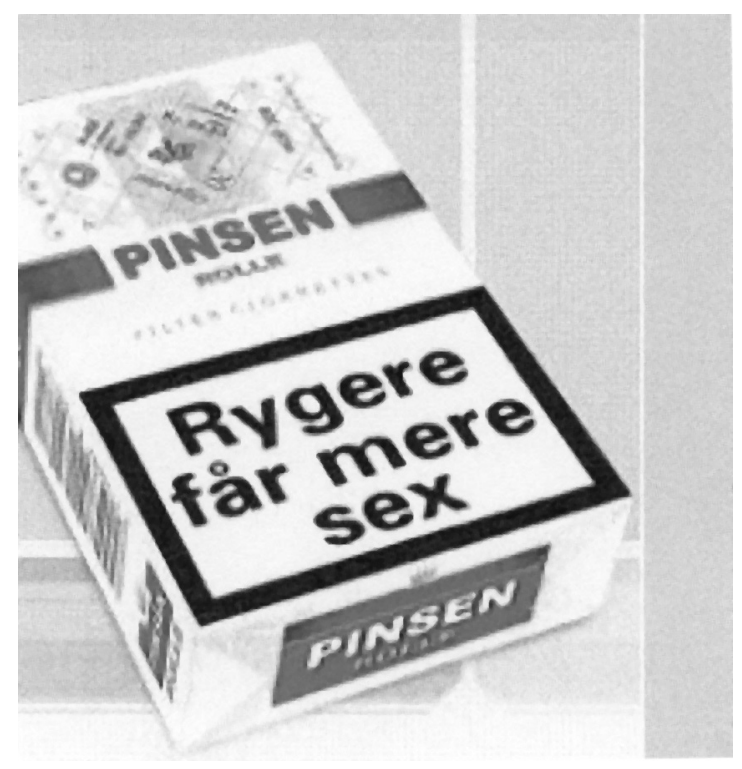

Debra Jones Ringold (2002) har samlet resultater fra en lang række undersøgelser om effekten af bl.a. ryge- og alkoholkampagner.

En repræsentativ undersøgelse viser f.eks. intet fald i antallet rygere pga. advarselslabels på cigaretpakker - tvært imod. I løbet af tre måneder var antallet af rygere steget. Forfatterne forklarer bl.a. resultatet med, at for repressive kampagner får folk til at gøre »oprør« - de viser deres individualitet og frihed ved at gøre det stikmodsatte af, hvad autoriteterne anbefaler. Dette understøttes af Krugman, Fox, Fischer (1999) der i deres reviewartikel diskuterer virkningen af advarsler på cigaretpakker.

De har en hypotese (som de dog ikke tester direkte) om, at for meget advarsel og skræk medfører en boomerang effekt, fordi cigaretter bliver oplevet som 'forbudden frugt'. De har nogle vigtige pointer om, at feltet hele tiden vil være i udvikling, og at rygning/advarsler/skræk er en praksis, der ændrer sig, fordi spørgsmålene om risici den forbindelse er komplekse. Derfor mener de heller ikke, at modellerne for om skræk virker har samme gyldighed i dag som for to år siden. De kritiserer bl.a. EPPMog PMT- modellerne for at være statiske og uden fokus på konteksten.

Ringold refererer til en undersøgelse, der peger på, at de mennesker, der har det største og mest regelmæssige alkoholforbrug afviser budskabet, mens de, der kun drikker af og til, i højere grad accepterer det. De individuelle forhold som tidligere erfaringer, livssituation generelt, årsag til handlinger (f.eks. hvis man bruger alkohol og rygning til at afstive sin identitet med) er, som allerede nævnt, væsentligt at holde sig for øje. Dette understøttes af andre undersøgelser bl.a. Bieners m.fl. 2000 og den danske test af australske antirygespot (Vilstrup Research 2003).

Witte m.fl. (2000) er ligeledes opmærksomme på negative effekter ved brug af skræk som virkemiddel. Hun nævner ikke risikoen for en boomrangeffekt, hvor budskabet kan føre til "negative« handlinger, men fokuserer på risiko for »fearcontrol«. Det betyder, at man risikerer, at modtageren i den valgte målgruppe vil afvise budskabet, hvis hun oplever det som en trussel, som hun ikke tror på, at hun kan imødegå ved handling.

Disse resultater peger på, at man skal være varsom med at bruge skræk over for de målgrupper, som ligger fjernest fra at ville eller kunne ændre deres handlinger, f.eks. de mest inkarnerede rygere eller alkoholbrugere. Derimod kan skræk virke befordrende for mennesker med et moderat forbrug, som allerede har tænkt tanken, at et stop eller en reduktion af rygningen ville være en positiv mulighed.

\section{Etisk og samfundsmæssig kompleksitet}

Uanset valg af budskab, henvendelsesform og virkemidler for en forebyggelses- eller sundhedskampagne, så er der tale om mere eller mindre bevidste valg af en bestemt viden og forståelse, som foretrækkes frem for andre tilgange. Alene i valget af et tema som »rygning « og ved udpegningen af det individuelle ansvar (»du ødelægger dit og dine omgivelsers helbred«) ligger en forståelse af, hvad 
der er sundt og på hvilket niveau, der skal appelleres til at denne sundhed styrkes. Man kunne antage, at indtagelsen af hormonlignende stoffer gennem kosten set $\mathrm{i}$ et forplantningsperspektiv var en nok så central problematik som rygning og man kunne overveje om udpegningen af det individuelle ansvar altid er det mest relevante. Faktorer som stress på arbejdspladsen, hvor cigaretten bliver pausesignal til rygeren selv og omgivelserne, kunne være en anden måde at tænke henvendelse om rygning, som ville sætte andre målgrupper og problemstillinger i søgelyset.

Bag den forskning, som er gennemgået i litteraturstudiet, ligger en forståelse af sundhed, som noget, den enkelte er individuelt ansvarlig for. Det er individet, der skal appelleres til for at få det til at agere sundt og dermed samfundsmæssigt ansvarligt overfor de evigt tyngende offentlige udgifter til sundhedsvæsenet. Sociologen Lone Scocozza påpeger i en artikel med titlen »Folkesundhed eller moralsk oprustning«, at

Tankegodset i folkesundhedsprogrammerne savner en grundlaggende analyse af de livsomstandigheder, der fremmer rygning og alkoholindtagelse og ligeledes af, hvad der fremmer fedme og ringe motion. Meget tyder på, at arbejdsbetingelser, herunder arbejdsorganisering og grad af indflydelse har betydning for såvel rygning som alkoholindtagelse, og at økonomi, boligforhold, miljo og fritidsfaciliteter har betydning for fedme og motion. (Scocozza; 83,2002)

En diskussion af skræk som virkemiddel tager for givet, at det ikke er livsomstændigheder, men den enkeltes livsstil, der skal fokuseres på. I forlængelse heraf ligger, at det er et medicinsk perspektiv på sundhed, som dominerer på bekostning af et hverdagslivsperspektiv. Sundhed refererer i den offentlige diskurs til en instrumentel værdi - nemlig som et middel til at undgå sygdom, mens sundhed set fra et hverdagskulturelt perspektiv i højere grad handler om at have det godt med sig selv og finde veje i det liv, man nu engang lever. Kultursociologen Eva Thune Jacobsen siger, at sundhedsprofessionelle frem for at fokusere på, hvorfor »de ikke gør, som vi siger«, må spørge sig selv: »Hvorfor vi ikke gør, som de siger?«(Jacobsen, 2002)

Set i dette perspektiv kan effekten af at bruge skræk som virkemiddel være en yderligere distancering mellem et medicinsk og et hverdagskulturelt perspektiv, hvilket diskussionerne af en mulig boomerang-effekt kan ses som et udtryk for. Effekten kan altså blive en yderligere venden sig væk fra sundhedsbudskaber, fordi de er for skræmmende, når handlemulighederne ikke opleves at være inden for rækkevidde - hvem kan fă 600 gram frugt og grønt i en 70-årig mand? og hvad gør man, når eneste virkelige glæde er at spise og man vejer mindst $50 \mathrm{~kg}$ for meget?

I den medicinske diskurs, som vi anser for at være den dominerende, såvel i det foretagne litteraturstudie som i samfundsdebatten, ligger, at viden antages at være en relativt entydig størrelse. Nogle sundhedsbudskaber er imidlertid mindre entydige end andre og udsagn som på ét tidspunkt synes entydige kan modsiges af senere forskning. I en artikel, påviser Olsen og Gøtzsche, at mammografiscreening i forbindelse med brystkræft kan skade snarere end gavne kvinders helbred. Deres undersøgelse viste, at dødeligheden hos de mammograferede kvinder samlet set var højere end i kontrolgruppen. En årsag hertil kan være, at screening fører til, at flere kvinder behandles for brystkræft, hvilket sker med strålebehandling, som øger risikoen for at få hjertesygdomme. (Olsen og Gøtzsche, 2001, her fra Scocozza, 2002)

Nogle udsagn er alene entydige i et afgrænset perspektiv. Derfor kan budskaber modsige hinanden. Hvis man både er disponeret for hjertekarsygdomme og brystkræft, kan budskaber om rødvin være lettere modsigende. Et til to glas rødvin om dagen er godt til at forebygge hjerte/karsygdomme, mens kræftlæger mener, at det kan fremme brystkræft. Ved valget af skræk som virkemiddel bliver det særligt relevant at overveje, hvilke andre sundhedsbudskaber, ens eget budskab kan modsige, fordi det kan være voldsomt for målgruppen at møde trusler om risiko for tab, der går $\mathrm{i}$ modstridende retninger.

Entydige udsagn, som udpeger entydige handlemuligheder, risikerer at opfordre folk til at gøre noget, som ud fra andre hensyn kan være problematisk. For et par år siden opstod der f.eks. diskussion om, hvorvidt solcreme gjorde mere skade end gavn på grund af de hormonlignende stoffer, som solcreme kan indeholde.

Viden om, hvad der er sundt og om, hvordan vi opnår det sunde er altså ikke altid entydig. Det be- 
tyder, at et skrækbudskab altid må ses som et valg af en sandhed, som fremlægges uden invitation til dialog om andre mulige sandheder - for eksempel dem målgruppen har fokus på. Derfor er det vigtigt ikke alene at tænke i valg af virkemidler, men nok så meget at have fokus på, hvilke muligheder for dialog, kampagnen lægger op til. Den 23-årige fyr, som selv har været impliceret i en trafikulykke kan gå i dialog med eleverne om risici og handlemuligheder, mens cigaretpakkens budskab blot kan modtages eller afvises.

Når viden om, hvad der er sundt og om, hvordan vi opnår det sunde langt fra er entydig, så bliver de etiske problemer i forbindelse med at formidle med skræk som virkemiddel centrale.

I den gennemgåede forskning om skræk forholder man sig primært til effektiviteten i forhold til at få et budskab igennem til modtageren og i sidste ende få modtageren til at ændre sine handlinger. Dermed er perspektivet afsenders: Hvilke midler kan en afsender bruge for at overvinde en eventuel modstand? Der spørges ikke: Hvilke overtalelsesmidler er det etisk acceptabelt at bruge for at nå sit mål: Hvornår manipuleres modtageren?

Som sagt er skræk mange ting, og den enkelte modtager opfatter skrækbudskaber individuelt. Men brug af skræk er ofte at vise den mest negative konsekvens af en handling. Her bliver det første etiske spørgsmål - skal man oplyse om sandsynligheden for, at det går så galt - eller skal man ikke? Jan Foght Mikkelsen mener i bogen »Formidlingsetik«, at det er manipulation, når man får teenagere til at tro, at de får HIV, hvis de ikke bruger kondom på trods af, at sandsynligheden er ekstremt lille. (Mikkelsen 1998) Modargumentationen vil være, at det er etisk korrekt at stave med store typer, når en bestemt handling kan medføre alvorlig sygdom og/eller død.

Et andet etisk spørgsmål, når man gennemfører massemedierede kampagner, som bruger skræk som virkemiddel er, hvilken virkning det har på personer uden for målgruppen. Bliver børn f.eks. unødigt angste for, at deres forældre dør af lungekræft, hvis de ryger?

En anden type etisk - eller politisk - problem i forhold til at formidle mulige risici ved en given hand- ling er, at der sættes fokus på denne og dermed på den gruppe mennesker, som qua deres handlinger er i risikozonen.

Er det etisk forsvarligt (og meningsfuldt) at appellere med skrækbudskaber til mennesker som qua deres livsomstændigheder har ringe mulighed for at agere $\mathrm{i}$ forhold til at ændre deres handlinger. Folk, der drikker for meget, har deres grunde til det, og det er et relevant spørgsmål, om en udstilling af deres handlinger som ekstremt uansvarlige, får dem til at føle sig bedre i stand til at ændre dem eller den snarere bidrager til en yderligere stigmatisering.

Det kan også være relevant at forholde sig kritisk til om opmærksomheden på problemet giver større problemer end problemet i sig selv - er det f.eks. så stigmatiserende at være tyk i dagens folkeskole, at det giver sociale og psykiske problemer, som overstiger de fysiske problemer med overvægten? På samme måde må man spørge sig selv, om problemet er lige stort for alle samfundsgrupper og hvis ikke om det så er relevant med en individuelt orienteret adfærdsmodificerende kampagnestrategi.

Endelig vil vi påpege, at det ikke alene er relevant at se på mulige effekter i forhold til at ændre individets handlinger. Øget brug af skræk som virkemiddel kan også ventes at have effekt på samfundsmæssige diskurser om sundhed og sygdom og på vores forsvarsberedskab i forhold til budskaber med stærke virkemidler, som vi ikke orker at forholde os til.

Der er ikke os bekendt nogen, som har diskuteret disse problematikker, men vi finder dem centrale at inddrage i overvejelser om valg af virkemidler. Konkurrencen om borgere og kunders opmærksomhed skærpes konstant, hvilket frister til at sætte trumf på sin kommunikation, men den langsigtede effekt kan være en generel immunisering overfor sundhedsbudskaber og man kan risikere en yderligere udstødelse og afstandtagen hos de grupper, som har sværest ved at handle i forhold til det budskab, kampagnen angår.

\section{Skræk som virkemiddel?}

En skræk-appel kan være mange ting. Fra et faktuelt udsagn på cigaretpakken til stærk følelsesmæssig 
appel i et videospot fra en trafikulykke. Fællestrækket er, at der er fokus på risiko for individuelt at lide tab, hvis man ikke følger en given opfordring til at ændre sine handlinger. For at afklare, hvad der opleves som skræk, må man skabe et indgående billede af kampagnens målgrupper.

I arbejdet med målgrupper må vi forholde os til den kompleksitet, som karakteriserer menneskers liv. Det går ikke alene at operere med statistiske demografiske data. Vi skal have fat i menneskers hverdagsliv og de specifikke kontekster og sociale relationer, hvor den problemstilling, vi gerne vil nå dem med, er relevant for dem. Mennesker tænker $o g$ handler ikke ens over tid og ofte er det erfaringer eller behov i den enkeltes hverdagsliv, som skal imødekommes af kampagnebudskabet, hvis de skal i gang med at gøre noget andet end de plejer.

Budskaber spredes i sociale netværk, hvor de forhandles og formes til noget, som er relevant $\mathrm{i}$ netværket. Autoritative budskaber, som ikke levner plads til alternative virkelighedsopfattelser, risikerer enten ikke at blive gjort til genstand for opmærksomhed i netværket eller at blive omformet i en modstandsdiskurs.

Det bliver derfor et centralt spørgsmål om et skrækbudskab kan være en invitation til dialog eller det opleves som et take-it-or-leave-it udsagn. I sidst nævnte tilfælde er der risiko for, at målgruppen overser eller reagerer imod det.

Bag den forskning, som er gennemgået i litteraturstudiet, ligger en forståelse af sundhed, som noget, den enkelte er individuelt ansvarlig for. Det er individet, der skal appelleres til for at få det til at agere sundt og dermed samfundsmæssigt ansvarligt. Samtidig præsenteres viden om sundhed som entydig og almen, hvilket hverken i en videnskabelig- eller hverdagslivsdiskurs holder for en nærmere undersøgelse.

Kort sagt, så skal man tænke sig særligt grundigt om inden man giver sig i kast med at bruge skræk som virkemiddel i sundhedskampagner. Men der er ikke grund til helt at forkaste skræk som virkemiddel. For personen, der har overvejet at holde op med at ryge, men blot ikke har taget sig sammen endnu, kan det at få udpeget risikoen for tab være sidste og afgørende skub. For handels- skoleklassen kan besøget af en jævnaldrende, der har været involveret i en trafikulykke, fordi hun kørte i beruset tilstand, være det skub, der gør, at eleverne lader bilen stå. Jo stærkere virkemiddel, man vælger at anvende, jo større bliver kravene til at afklare målgruppens hverdagslivsforståelse, relevansoplevelse og den kontekst, budskabet skal i dialog med. Ligeledes bliver det centralt at afklare budskabets videnskabelige grundlag og at overveje, hvordan andre perspektiver på budskabet kan være relevante og eventuelt kan gives stemme i kampagnens design. Endelig må refleksion omkring en mulig stigmatisering af mennesker, som ikke handler i overensstemmelse med budskabet, og konsekvenser heraf, inddrages. Så en kort sammenfatning lyder: Lad dig ikke forføre af simple lineære forståelser og lad dig ikke handlingslamme af kritiske komplekse problematiseringer!

\section{Referencer}

Australia's National Tobacco Campaign (2000). Evaluation Report volume Two. Commonwealth of Australia.

Biener, L., McCallum-Keeler, G., Nyman, A.L. (2000): 'Adults' response to Massachusetts anti-tobacco television advertisements: impact of viewer and advertisement characteristics' in Tobacco Control, vol. 9, p. 401-407

Bourdieu, P. (1990) The Logic of Practice, Cambridge, Polity Press

Bourdieu, P. og Wacquant L. (1996) Refleksiv sociologi - mål og midler, København, Hans Reitzels Forlag

Collins, C., Davies, Linda S., Rentz, K., Vannoy, D. (1997) 'Influence of advertisement on women's attitudes toward mammography screening' Issues in Mental Health Nursing, vol. 18, p. 603-621

Dahl, H. (1993). Har du overvejet at endre hele dit liv? i Dansk Sociologi 1, Dansk Sociologiforening p 20-34

Das, E. H., de Wit, J.B.F (2003): Fear Appeals Motivate Acceptance of Acion Recommendations: Evidence for a Positive Bias in the Processing of Persuasive Messages' in Personality and Social Psychology Bulletin, vol. 29, no. 5

Dervin, Brenda (1989). Audience as Listener and Learner, Teacher and Confidante: The Sense-Making Approach. p 67-86 in R.ice, R.E. and Atkin (eds) Public Communication Campaigns, London, Sage Publications

Dervin, B. and Foreman-Wernet, L (2003) Sense-Making - Methodology Reader - selected writings of Brenda Dervin. Cresskill, Hampton Press

Floyd D.L., Prentice-Dunn S. Rogers R.W. (2000): A metaanalysis of research on Protection Motivation Theory in Journal of Applied Social Psychology, 22, 55-69

Hovland (1953) in Janis IL and Kelley HN. Communication and Persuasion, Yale University Press, Ner Haven Communication 
Jacobsen, E.T. (2002). Retten til usundhed? i Social Kritik 84 p. $90-97$

Jonson K.A. og La Tour M. (1991). AIDS Prevention and College Students: Male and Female Responses to»Fear-Provoking» Messages. Health Marketing Quarterly, vol. 8, issue 3/4

Keller, P.A. (1999). Converting the Unconverted: The Effect of Inclination and Opportunity to Discount Health-Related Fear Appeals. Journal of Applied Psychology, vol. 84, no. 3, p. 403-415.

Keller, P.A., Block, L.G. (1996). Increasing the Persuasiveness of Fear Appeals: The Effect of Arousal and Elaboration. Journal of Consumer Research, vol. 22, issue 4

Kline, Kimberly Nicole; Mattson, Marifran (2000) 'Breast Self-examination Pamphlets: A Content Analysis Grounded in Fear Appeal Research' in Health Communication, , vol. 12 , iss. 1

Krugman, D.M, Fox, R.J, Fischer, P.M. (1999) 'Do Cigarette Warnings Warn? Understandning What It Will Take to Develop More Effective Warnings' in Journal of Health Communication, vol 4, iss. 2

McGuire, William (1989). Theoretical Foundations of Campaigns, in: Ronald E. Rice \& William J. Atkin

Mikkelsen, Jan Foght (2002) Etik eller effektivitet? Bidrag til en formidlingsetik, Frederiksberg, Samfundslitteratur

Poulsen, J. (1999). Kultur og betydning - Kommunikation som kulturel og social praksis, Samfundslitteratur..

Prochaska, J.O. (1994). Changing for good, New York, Avon Books

Prochaska J., DiClemente C., Norcross J. (1992): In Search of How People Change - Applications to Addictive Behaviors in American Psychologist, vol 47 nr. 9 p 1102-1114

Ringold, D.J. (2002) Boomerang Effect: In Response to Public Health Interventions: Some Unintended Consequences in the Alcoholic BeverageMarket. Journal of Consumer Policy, vol. 25 , p. $27-63$

Rise, J. (2001): 'En Socialpsykologisk analyse av eet fryktvekkende budskap: en kvasieksperimentell undersøkelse' Statens Tobakksskaderåd, Norge.

Rogers, E.M. (1995). Diffusion of Innovations, The Free Press.

Rogers, R.W. (1983): Cognitive and physiological processes in fear appeals and attitude change: A revised theory of protection motivation. In: Cacioppo J, Petty R. eds. Social psychophysiology. New York: Guilford, 153-176

Schutz, A. (1975). Hverdagslivets sociologi. København, Hans Reitzels Forlag
Scocozza, L. (2002) Folkesundhed eller moralsk oprustning? i Social Kritik 84 p 79-89

Stephenson, M. T.; Witte, K. (1998) 'Fear, threat, and perceptions of efficacy from frightening skin cancer messages' Public Health Reviews vol. 26 p. 147-174

Struges, J. W., Rogers RW. (1996) Preventive Health Psychology From a Developmental Perspective: An Extension of Protection Motivation Theory in Health Psychology, , Vol 15, No. 3

Vilstrup Research (2003): Add + impact test af 4 reklamer. Marts/April 2003

Windahl, Olson og Signitzer, (1998): Using Communication Theory,

Witte, K.; Allen, M. (2000): A Meta-Analysis of Fear Appeals: Implications for Effective Public Health Campaigns' in Health Education \& Behavior, vol 27, iss. 5

Birgitte Ravn Olesen er lektor ved Institut for Kommunikation Roskilde Universitetscenter, cand.com Tine Mark Jensen er ekstern lektor ved Institut for Kommunikation Roskilde Universitetscenter og Nina Blom Andersen er ph.d.-stpendiat ved Institut for Kommunikation Roskilde Universitetscenter.

\section{Noter}

1 I litteratursøgningen ønskede vi at fokusere på tekster fra 1995 og fremefter og fra lande, som Danmark normalt sammenligner sig med og/eller som har brugt skræmmevirkemidler over længere tid fx Norge, Sverige, Holland og Australien. I praksis viste det sig, at der primært findes amerikansk litteratur om emnet.

2 Materialet fra litteratursøgningen er af varieret kvalitet hvad angår undersøgelsesdesign og efterfølgende konklusioner. De fleste studier udspringer af amerikansk behavioristisk psykologiforskning. Metodisk er de fleste undersøgelser lavet som laboratorieeksperimenter med en lille gruppe mennesker, der er blevet udsat for skrækstimuli og en del er ikke afprøvet på den relevante målgruppe, men på studerende. Derudover sammenlignes studier med ganske forskellige emner som f.eks. rygning og brystselvundersøgelser til forebyggelse af kræft. Ingen diskuterer om nogle emner og budskaber er mere velegnede til at formidle med skræk end andre. 